\title{
TOTAL QUALITY MANAGEMENT TERHADAP KINERJA MANAJERIAL DENGAN SISTEM PENGUKURAN KINERJA SEBAGAIVARIABEL MODERATING PADA FAJAR GRUP
}

\author{
Wawan Darmawan, Teri \\ Universitas Fajar, Universitas Fajar \\ wawan.unifa@gmail.com
}

\begin{abstract}
Total Quality Management (TQM) is one technique that is often used by companies in order to improve its performance.The aims of the research were to (1) determine and test whether total quality management (TQM)has positive effect on managerial performance at Fajar Group, (2) determine and test whether TQM measurement has effect on managerial performance at Fajar Group, (3) determine and test whether measurement system of TQM has a role as moderating variable between TQM and managerial performance at Fajar Group. The research was a quantitative study conducted in companies belonging to Fajar Group. The population consisted of 58 respondents taken from 24 companies by considering the number of managers at mid-level of each company. The measurement wasdone using quantitative data with Moderated Regression Analysis (MRA) analysis. The results of the research indicate that (1) TQM has positive effect on managerial performance, (2) performance measurement system has positive effect on managerial performance at Fajar Group, (3) TQM interaction with performance management system has effect on managerial performance at Fajar Group.
\end{abstract}

Keyword: total quality management, managerial performance.

\begin{abstract}
ABSTRAK
Total Quality Management (TQM) merupakan salah satu teknik yang sering digunakan oleh perusahaan dalam rangka meningkatkan kinerjanya, Penelitian ini bertujuan mengetahui dan menguji: (1) pengaruh positif TQM terhadap kinerja manajerial pada Fajar Grup; (2) pengaruh positif sistem pengukuran kinerja terhadap kinerja manajerial pada Fajar Grup; (3) sistem pengukuran kinerja berperan sebagai variabel moderasi antara TQM dengan kinerja manajerial pada Fajar Grup. Penelitian ini merupakan jenis penelitian kuantitatif terhadap perusahaan yang tergabung dalam Fajar Grup. Jumlah sampel mempertimbangkan aspek jumlah manajer tingkat menengah untuk tiap-tiap perusahaan, yakni dari 24 perusahaanditetapkan sebanyak 58 responden. Oleh karena jumlah anggota populasi relatif kecil, seluruh anggota populasi akan dijadikan sebagai sampel denganukuran sampel dalam penelitian ini sebanyak 58 orang. Data dianalisis dengan menggunakan teknik analisis moderated regression analysis (MRA). Hasil penelitian menunjukkan bahwa: (1) total quality management berpengaruh positif terhadap kinerja manajerial pada Fajar Grup; (2) sistem pengukuran kinerja berpengaruh positif terhadap kinerja manajerial pada Fajar Grup; (3) interaksi TQM dengan sistem pengukuran kinerja mempengaruhi kinerja manajerial pada Fajar Grup.
\end{abstract}

Kata Kunci: total quality management, kinerja manajerial, sistem pengukuran kinerja. 


\section{Pendahuluan}

Berkembangnya sistem akuntansi manajemen kontemporer merupakan re-aksi terhadap perubahan signifikan pada lingkungan bisnis yang dihadapi oleh perusahaan manufaktur dan perusahaan jasa. Sistem akuntansi manajemen kon-temporer secara keseluruhan bertujuan untuk kepuasan, meningkatkan kualitas, relevansi, serta penetapan waktu infor-masi biaya (Hansen \& Mowen, 2004). Salah satu aspek yang penting sistem akuntansi manajemen kontemporer terse-but adalah Total Quality Management (TQM). TQM membuat perusahaan dapat tetap bersaing dengan perusahaan-peru-sahaan lain karena konsep dasarnya yaitu perbaikan secara berkala atau terus-menerus. Selain itu, TQM merupakan proses yang memiliki orientasi ke kon-sumen dengan mengintegrasikan antara praktek manajemen dasar dan usaha-usaha perbaikan yang sering dipakai serta teknik dan peralatan-peralatan handal. TQM dapat diterapkan untuk setiap perusahaan kecil maupun perusahaan, industri jasa atau manufaktur, dan juga organisasi swasta atau publik. TQM juga diakui dapat membantu meningkatkan produktivitas, kepuasan karyawan, dan kepuasan konsumen (Wolner, 1992).

Bagi beberapa perusahaan, sistem akuntansi manajemen kontemporer bermanfaat untuk mempresentasikan pembebanan biaya yang lebih akurat dan terinci melebihi biayanya. Aspek penting dari perubahan ini adalah: perspektif lintas fungsional, orientasi kepada pelanggan, manajemen mutu terpadu (TQM), persaingan global, waktu sebagai unsur kompetitif, kemajuan lingkungan manufaktur, kemajuan dalam teknologi informasi, manajemen berdasarkan aktivitas, serta pertumbuhan dan deregulasi dalam indus-tri jasa (Hansen \& Mowen, 2004).
TQM merupakan salah satu teknik yang sering digunakan oleh perusahaan dalam rangka meningkatkan kinerjanya, oleh karena itu penelitian tentang peng-gunaan TQM dan sistem akuntansi ma-najemen secara interaktif yang mempe-ngaruhi kinerja perusahaan menjadi salah satu topik yang menarik. Penerapan TQM mampu membuat beberapa perusahaan berhasil meningkatkan kinerjanya namun tidak sedikit juga yang belum mampu meningkatkan kinerja mereka, dan hanya sedikit bukti empiris yang menguji alasan penyebab hasil penerapan teknik TQM yang tidak konsisten (Powell, 1995). Ini berarti bahwa secara universal tidak ada sistem akuntansi manajemen yang selalu bisa bisa diterapkan pada organisasi, karena hal ini tergantung juga pada alasan kondisional pada organisasi tersebut. Penyebab kinerja perusahaan rendah me-nurut beberapa peneliti bidang akuntansi disebabkan oleh sistem akuntansi mana-jemen perusahaan tersebut gagal dalam menentukan ukuranukuran kinerja, sasa-ran-sasaran yang tepat, dan sistem peng-hargaan (Bankeret al., 1993).

Peneliti lainnya dilakukan oleh Wruck \& Jensen (1994), yang melakukan pengujian faktor-faktor penyebab keti-dakefektifan penerapan TQM menemu-kan bahwa efektivitas penerapan TQM memerlukan perubahan mendasar pada infrastruktur organisasional, meliputi: sis-tem pengukuran kinerja, sistem penghar-gaan serta hukuman, dan sistem alokasi wewenang pembuatan keputusan. Temu-an lainnya dilakukan Itter \& Larcker (1995), yang menemukan bukti bahwa organisasi yang mempraktekkan sistem akuntansi manajemen dan TQM tidak dapat mencapai kinerja yang tinggi.

Pernyataan berbeda dikemukakan oleh peneliti lain yaitu Khim \& Larry(1998), yang menemukan adanya penga-ruh interaktif (bersama-sama) antara praktik penerapan 
TQM dengan desain sistem akuntansi manajemen terhadap kinerja. Lebih lanjut Khim \& Larry (1998), menyatakan bahwa praktek TQM yang efektif memerlukan perubahan dalam sistem akuntansi manajemen yang terdiri dari diseminasi informasi lintas hirarki organisasional, pengumpulan in-formasi baru, perubahan sistem reward, ukuran kerja dan tujuan kinerja.

Dari hasil penelitian yang kon-tradiksi tersebut, perlu dilakukan pene-litian untuk merekonsiliasi hasil-hasil penelitian sebelumnya yang tidak konsis-ten tersebut untuk mengetahui apakah interaksi praktik penerapan TQM dan sis-tem akuntansi manajemen berpengaruh terhadap kinerja. Penelitian ini mencoba menguji temuan dari Khim \& Larry (1998), yang fokus pada TQM/JIT dan tiga komponen utama sistem akuntansi manajemen yang salah satunya adalah sistem pengukuran kinerja pada tingkat organisasional serta kinerja berdasarkan pada kualitas dan keuangan yang dite-rapkan pada tingkat operasi produksi pada Fajar Grup, yaitu grup perusahaan yang membawahi banyak perusahaan media yang pada prinsipnya telah mene-rapkan TQM. Perusahaan ini tidak terle-pas dari fenomena kualitas dan kuantitas.

Fajar Grup dalam era globalisasi, di satu pihak diperhadapkan pada keku-atankekuatan dan masalah-masalah inte-ren yang ada. Sedangkan di lain pihak, secara bersamaan juga diperhadapkan pa-da kondisi lingkungan dengan berbagai faktor peluang dan tantangan yang senan-tiasa berkembang dinamis. Adanya peru-sahaan pesaing menjadi tantangan ter-sendiri untuk dapat bertahan hidup. Hal ini tentu saja membutuhkan optimalisasi fungsi-fungsi manajemen, inilah yang menjadi permasalahan dalam penelitian ini, khususnya masalah sistem pengu-kuran kinerja yang terdapat pada Fajar Grup. Sistem pengukuran kinerja ke-mungkinan dapat mempengaruhi penera-pan TQM yang juga akan dapat mempengaruhi kinerja manajerial.

Berdasarkan pada latar belakang yang telah diuraikan di atas, maka penulis merumuskan masalah penelitian yaitu apakah TQM dan sistem pengukuran kinerja serta interaksi diantara keduanya berpengaruh positif terhadap kinerja manajerial pada Fajar Grup. Tujuan yang ingin dicapai dalam penelitian ini adalah untuk mengetahui dan menguji apakah TQM dan sistem pengukuran kinerja serta interaksi diantara keduanya berpengaruh positif terhadap kinerja manajerial pada Fajar Grup.

\section{Rumusan Masalah}

Berdasarkan pada latar belakang yang telah diuraikan di atas, maka pene-liti merumuskan masalah sebagai berikut:

1. Apakah TQM berpengaruh positif terhadap kinerja manajerial pada Fajar Grup.

2. Apakah sistem pengukuran kinerja berpengaruh positif terhadap kinerja manajerial pada Fajar Grup.

3. Apakah sistem pengukuran kinerja berperan sebagai variabel moderasi antara TQM dengan kinerja mana-jerial pada Fajar Grup.

\section{Kajian Literatur}

Total Quality Management (TQM) sebagai solusi

Berangkat dari hasil penelitian-penelitian yang kontradiksi, peneliti me-rasa perlu melakukan penelitian untuk merekonsiliasi hasil-hasil penelitian sebe-lumnya yang tidak konsisten tersebut un-tuk mengetahui apakah interaksi praktik penerapan TQM dan sistem akuntansi manajemen berpengaruh terhadap kinerja. Penelitian ini mencoba menguji temuan dari Khim \& Larry (1998), yang fokus pada 
TQM/JIT dan tiga komponen utama sistem akuntansi manajemen yang salah satunya adalah sistem pengukuran kinerja pada tingkat organisasional serta kinerja berdasarkan pada kualitas dan keuangan yang diterapkan pada tingkat operasi produksi pada Fajar Grup, yaitu grup perusahaan yang membawahi banyak pe-rusahaan media yang pada prinsipnya telah menerapkan TQM. Perlu diingat Fajar Grup termasuk perusahaan yang tidak terlepas dari fenomena kualitas dan kuantitas.

Kualitas menjadi hal utama yang menjadi titik fokus setiap perusahaan. Berbagai hal dilakukan untuk mening-katkan kualitas yang diterapkan pada produk, pelayanan dan manajemen peru-sahaan. Menurut Garrison (2000) "ken-dala atau constraint adalah segala sesuatu yang menghambat Anda untuk mendapat-kan apa yang anda inginkan". Oleh kare-na itu, pengelolaan berdasarkan Theory of Constraints menjadi faktor kunci sukses. Perusahaan dituntut untuk dapat menga-tasi kendala agar kinerja manajerialnya dapat menjadi lebih baik sehingga tidak mengganggu kelangsungan hidup perusa-haan. Salah satu alat yang dianggap dapat membantu memperbaiki kinerja manaje-rial dalam mencapai tujuan peningkatan laba adalah Total Quality Management (TQM). Total Quality Management se-cara harafiah berasal dari kata "total" yang berarti keseluruhan atau terpadu, "quailty" yang berarti kualitas, dan "management" telah disamakan dengan manajemen dalam bahasa Indonesia yang diartikan dengan pengelolaan. Jadi dari asal katanya total quality management dapat diartikan manajemen mutu terpadu atau manajemen kualitas terpadu.

Penelitian ini mengajukan pada suatu model yang menghubungkan antara Total Quality Management (TQM) de-ngan kinerja manajerial yang dimoderasi oleh sistem pengukuran kinerja. Khim \& Larry (1998) membangun suatu kerangka konsep untuk meneliti hubungan antara praktik penerapan TQM dengan desain sistem akuntansi manajemen terhadap kinerja. Temuan Khim \& Larry fokus pada TQM/JIT dan tiga komponen utama sistem akuntansi manajemen yaitu sistem pengukuran kinerja, sasaran-sasaran ki-nerja, dan sistem penghargaan pada ting-kat organisasional serta kinerja berdasar-kan pada kualitas dan keuangan. Mereka menyatakan bahwa terdapat pengaruh interaktif antara praktik penerapan TQM dengan desain sistem akuntansi mana-jemen terhadap kinerja. Dengan demikian efektifitas praktek TQM membutuhkan perubahan-perubahan dalam sistem akun-tansi manajemen.

Berdasarkan hasil penelitian sebelumnya, penelitian ini membangun sebuah kerangka konseptual dengan menghubungkan antara Total Quality Management (TQM) dengan kinerja manajerial yang dimoderasi oleh sistem pengukuran kinerja, yang dapat dilihat pada skema sebagai berikut:

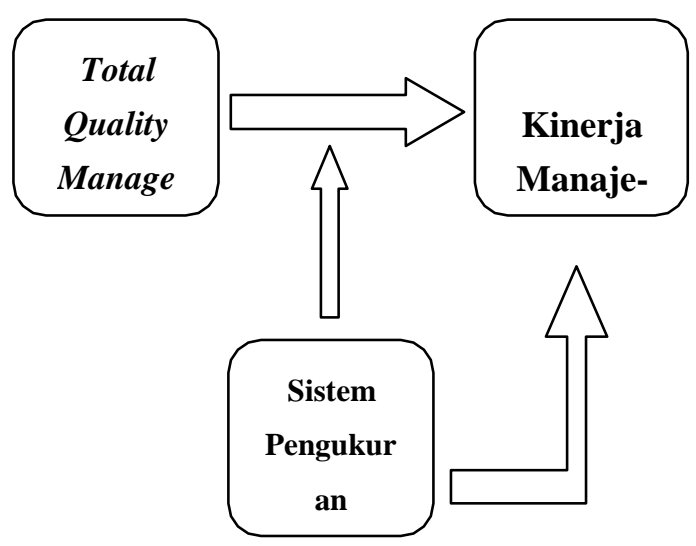

Gambar 1. Model Pengaruh TQM dan Sistem Pengukuran Kinerja terhadap Kinerja Manajerial 


\section{Prinsip Utama dalam Total Quality Management (TQM)}

Joseph M Juran (McLeod \& Schell, 2008), berpendapat bahwa kua-litas dapat disarikan menjadi tiga proses dasar yaitu "perencanaan kualitas, pe-ngendalian kualitas, dan perbaikan kua-litas". Proses-proses ini disebutnya trilogi kualitas. Menurut Nasution (2005) ada sepuluh karakteristik TQM yang dikem-bangkan oleh Goetsch \& Davis, yaitu:

a. Kepuasan Pelanggan

Dalam TQM, baik pelanggan internal maupun pelanggan eksternal meru-pakan driver. Pelanggan eksternal menentukan kualitas produk atau jasa yang disampaikan kepada mereka, sedangkan pelanggan internal ber-peran besar dalam menentukan kua-litas tenaga kerja, proses, dan ling-kungan yang berhubungan dengan produk atau jasa.

b. Obsesi terhadap Kualitas

Dalam organisasi yang menerapkan TQM, pelanggan internal dan eks-ternal menentukan kualitas. Dengan kualitas yang ditetapkan tersebut, organisasi harus terobsesi untuk me-menuhi atau melebihi apa yang diten-tukan mereka. Hal ini berarti, bahwa semua karyawan pada setiap level berusaha melaksanakan setiap aspek pekerjaannya berdasarkan perspektif. Bagaimana kita dapat melakukannya dengan lebih baik? Bila suatu orga-nisasi terobsesi dengan kualitas, maka berlaku prinsip „good enough is never good enoughee.

Pendekatan Ilmiah

Pendekatan ilmiah sangat diperlukan dalam penerapan TQM, terutama un-tuk mendesain pekerjaan dan dalam proses pengambilan keputusan dan pemecahan masalah yang berkaitan dengan pekerjaan yang didesain ter-sebut. Dengan demikian, data diper-lukan dan dipergunakan dalam me-nyusun patok duga (benchmark), me-mantau prestasi, dan melaksanakan perbaikan.

c. Komitmen Jangka Panjang

TQM merupakan suatu paradigma baru dalam melaksanakan bisnis. Untuk itu, dibutuhkan budaya peru-sahaan yang baru pula. Oleh karena itu, komitmen jangka panjang sangat penting guna mengadakan perubahan budaya agar penerapan TQM dapat berjalan dengan sukses.

d. Kerjasama Tim

Dalam organisasi yang dikelola secara tradisional seringkali diciptakan persaingan antar departemen yang ada dalam organisasi tersebut agar daya saingnya terdongkrak. Sementara itu, dalam organisasi yang menerapkan TQM, kerjasama tim, kemitraan, dan hubungan dijalin dan dibina, baik an-tar karyawan perusahaan maupun de-ngan pemasok, lembaga-lembaga pe-merintah, dan masyarakat sekitarnya.

e. Perbaikan sistem secara berkesinam-bungan

Setiap produk dan atau jasa dihasilkan dengan memanfaatkan proses-proses tertentu di dalam suatu sistem/lingku-ngan. Oleh karena itu, sistem yang ada perlu diperbaiki secara terus-menerus agar kualitas yang dihasilkannya dapat makin meningkat.

Pendidikan dan Pelatihan.

Dewasa ini masih terdapat perusahaan yang menutup mata terhadap penting-nya pendidikan dan pelatihan karya-wan. Kondisi seperti itu menyebabkan perusahaan yang bersangkutan tidak berkembang dan sulit bersaing dengan perusahaan lainnya, apalagi dalam era persaingan global. Sedangkan dalam organisasi yang menerapkan TQM, pendidikan dan pelatihan merupakan faktor yang fundamental. Setiap orang 
diharapkan dan didorong untuk terus belajar. Dengan belajar, setiap orang dalam perusahaan dapat meningkat-kan keterampilan teknis dan keahlian profesionalnya.

f. Kebebasan yang terkendali

Dalam TQM, keterlibatan dan pemberdayaan karyawan dalam pengam-bilan keputusan dan pemecahan masa-lah merupakan unsur yang sangat penting. Hal ini dikarenakan unsur tersebut dapat meningkatkan „rasa memiliki dan tanggung jawab karya-wan terhadap keputusan yang telah dibuat. Meskipun demikian, kebeba-san yang timbul karena keterlibatan dan pemberdayaan tersebut merupa-kan hasil dari pengendalian yang terencana dan terlaksana dengan baik.

g. Kesatuan Tujuan

Supaya TQM dapat diterapkan de-ngan baik, maka perusahaan harus memiliki kesatuan tujuan. Dengan de-mikian, setiap usaha dapat diarahkan pada tujuan yang sama. Akan tetapi, kesatuan tujuan ini tidak berarti bah-wa harus selalu ada persetujuan/ kesepakatan antara pihak manajemen dan karyawan, misalnya mengenai upah dan kondisi kerja.

h. Adanya Keterlibatan dan Pemberda-yaan Karyawan

\section{Manfaat Total Quality Management (TQM)}

Manfaat TQM adalah memper-baiki kinerja manajerial dalam mengelola perusahaan agar dapat meningkatkan penghasilan perusahaan. Ada beberapa keuntungan pengendalian mutu yang digambarkan Ishikawa (1992) dalam bukunya, antara lain:

a. pengendalian mutu memungkinkan untuk membangun mutu di setiap langkah proses produksi demi meng-hasilkan produk yang $100 \%$ bebas cacat, b. pengendalian mutu memungkinkan perusahaan menemukan kesalahan atau kegagalan sebelum akhirnya be-rubah menjadi musibah bagi peru-sahaan,

c. pengendalian mutu memungkinkan desain produk mengikuti keinginan pelanggan secara efisien sehingga produknya selalu dibuat sesuai pilihan pelanggan,

d. pengendalian mutu dapat membantu perusahaan menemukan data-data produksi yang salah.

TQM juga digunakan untuk memperbaiki posisi persaingan perusa-haan di pasar dan sebagai alat untuk meningkatkan kemampuan dalam meng-hasilkan output dengan mutu berkualitas. "Produk yang berkualitas yang mampu memenuhi kebutuhan dan kepuasan kon-sumen secara berkelanjutan (sustainable satisfaction) akan menimbulkan pembe-lian yang berkelanjutan yang pada ak-hirnya dapat meningkatkan produktivitas perusahaan mencapai skala ekonomi dengan akibat penurunan biaya produksi” (Ibrahim, 2000).

\section{Manfaat Total Quality Management (TQM)}

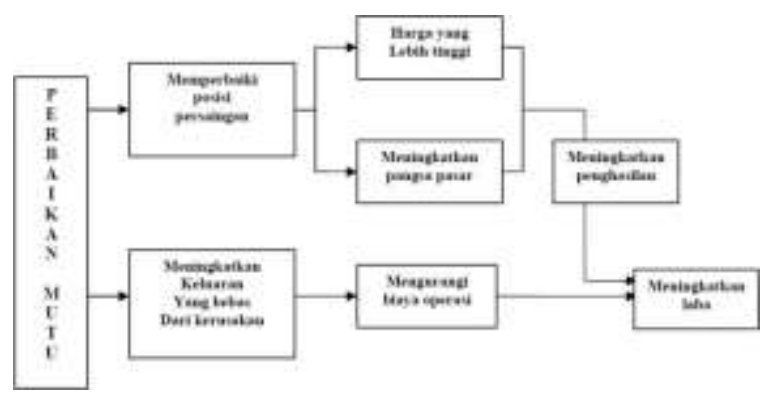

Gambar 2.Manfaat Total Quality Management (TQM)

Sumber : Stephen (1994) 


\section{TQM dan Kinerja Manajerial}

Kinerja manajerial diharapkan mampu dihasilkan oleh seseorang yang memegang posisi manajerial dengan kata lain kinerja manajerial bersifat abstrak dan komplek, ini berbeda dengan kinerja karyawan yang umumnya bersifat kong-krit. Manajer menghasilkan kinerja de-ngan mengarahkan kemampuan dan bakat, serta usaha beberapa orang lain yang berada di dalam daerah wewe-nangnya (Mulyadi \& Setiawan, 2001).

Hasil penelitian dari Tersziovski \& Samson (1999) tentang elemen-elemen TQM yang dijadikan sebagai sistem penghargaan kualitas, melakukan uji hu-bungan antara faktor elemen TQM yang dipilih terhadap faktor kinerja, dan ha-silnya adalah faktor elemen TQM mem-pengaruhi kinerja. Penelitian yang dila-kukan oleh Madu \& Kuei (1996) menun-jukan bahwa ada hubungan antara kinerja organisasional dan kualitas, sehingga penting bagi perusahaan untuk mema-hami indikator-indikator kritis dalam dimensi kualitas yang mempengaruhi kinerja organisasi.

\section{TQM, Sistem Pengukuran Kinerja, dan Kinerja Manajerial}

Praktek TQM/JIT saat ini mendo-rong aliran informasi ke karyawan yang melaksanakan tugas tersebut secarakon-tinyu. Banker, et al. (1993) dalam peneli-tiannya memberikan bukti empiris bahwa frekuensi pelaporan ukuran kinerja manu-faktur pada karyawan, terkait dengan praktik TQM, implementasi Just-In-Time (JIT), dan kerja sama tim. Jika perusahaan telah mengimplementasikan cara-cara un-tuk memperbaiki kualitas secara kontinyu atau terus-menerus maka program pening-katan kualitas seperti TQM secara indivi-dual bisa efektif, jika dibandingkan de-ngan perusahaan pesaing yang menga-dakan perbaikan dengan tidak menggu-nakan teknik TQM.
Penelitian lain dilakukan oleh Milgrom \& Roberts (1990) yang membe-rikan kerangka teoritis yang mencoba menunjukan isu mengenai, bahwa kinerja dipengaruhi oleh hubungan antara sistem pemanufakturan. Mereka menyatakan bahwa untuk menghasilkan kinerja yang lebih tinggi dari apa yang akan dicapai oleh sistem produk itu sendiri ditunjang oleh berhasilnya implementasi dari teknik pemanufakturan baru yang membutuhkan komplemen-komplemen sistem akuntansi manajemen yang dapat diinteraksikan de-ngan sistem produksi.

Dukungan empiris tentang kebera-daan komplemen-komplemen tersebut antara lain dari Daniel \& Reitsperger (1991) memberikan bukti empiris yang menunjukan bahwa perusahaan elektronik dan mobil di Jepang yang menggunakan strategi peningkatan terus menerus dalam meningkatkan kinerjanya, frekuensi memberikan umpan balik kinerja ditingkatkan. Sarkar (1997) menemukan bahwa bila pembagian informasi dinya-takan dalam bagian pekerjaan maka pro-ses peningkatan kualitas akan meningkat. Dari sudut pandang pembelajaran, kar-yawan dapat mengembangkan efektifitas pekerjaan strategis dengan lebih cepat dan dapat meningkatkan kinerjanya jika dibantu oleh tingginya frekuensi pela-poran pengukuran kinerja (Locke \& Latham, 1990).

Chenhall (1997) memberikan bukti yang menyatakan bahwa manajer mengevaluasi dan menguji kembali bagaimana komplemen-komplemen dalam program TQM meningkatkan profitabilitas yang memadai. Hal ini didorong oleh penguku-ran kinerja yang memberikan umpan ba-lik dalam bentuk pengendalian strategis. Chenhall menambahkan bahwa frekuensi umpan balik kinerja dan tingkat pembelajaran karyawan akan meningkat jika 
karyawan menerima pengukuran kinerja non keuangan, sehingga akan lebih baik bila kualitas dihubungkan secara lang-sung dengan pengukuran kinerja, oleh karena itu karyawan diwajibkan untuk memastikan bahwa kualitas dalam proses pemanufakturan tetap pada pengawasan dan dapat secara terus-menerus diting-katkan hasilnya.

Beberapa praktisi akuntansi sudah mulai mengakui bahwa jika mereka menginginkan untuk mempertahankan posisinya sebagai sumber utama terhadap pelaporan kinerja dalam organisasi, maka mereka seharusnya harus menyadari perubahan yang terjadi dalam pemanufakturan atau organisasi manufaktur (Simon, 1990). Tingginya perhatian ter-hadap perlunya perbaikan bagi para con-troller dalam pelaporan operasi perusa-haan berdasarkan pengukuran kinerja menunjukkan bahwa sistem akuntansi manajemen bukan lagi merupakan tugas yang baru bagi akuntan (Johnson \& Kaplan 1997).

\section{Metodologi penelitian Jenis Penelitian}

Jenis penelitian yang akan digu-nakan dalam penelitian ini adalah jenis penelitian kuantitatif dimana pengukuran dilakukan dengan menggunakan data kuantitatif dengan teknik analisis data statistik deskriptif dan analisis regresi.

\section{Objek Penelitian}

Objek yang dipilih dalam pene-litian ini adalah Fajar Grup yang terdiri dari beberapa perusahaan dengan alasan bahwa implementasi TQM dalam mengu-kur kinerja manajerial perusahaan yang tergabung dalam Fajar Grup merupakan langkah strategikyang berdampak besar terhadap kemampuan manajemen perusa-haan dibawah Fajar Grup dalam mening-katkan kinerjanya, diharapkan mereka akan mampu bersaing serta berkembang dengan baik.

\section{Populasi, Sampel, dan Teknik Pengambilan} Sampel

Populasi yang digunakan dalam penelitian ini seperti penelitian lainnya yang melakukan pengujian terhadap pe-nerapan TQM dalam peningkatan kinerja manajerial, adalah manajer secara indi-vidual sebagai unit analisis yang tersebar di seluruh perusahaan yang tergabung dalam Fajar Grup yang berjumlah 24 perusahaan. Respondennya adalah mana-jer tingkat menengah dari semua perusa-haan yang tergabung dalam Fajar Grup dengan pertimbangan: (1) Manajer ting-kat menengah umumnya biasanya terlibat langsung dengan kebijakan yang dilaksanakan oleh manajemen puncak; (2) Ma-najer tingkat menengah adalah pelaksana keputusan manajemen puncak yang mam-pu berinteraksi manajemen puncak dan karyawan.

Penentuan jumlah sampel pada penelitian ini mempertimbangkan aspek jumlah manajer tingkat menengah untuk masing-masing perusahaan. Setiap perusahaan yang tergabung dalam Fajar Grup memiliki struktur organisasi yang berbeda yang tentu saja ikut mempengaruhi jum-lah manajer tingkat menengah yang ber-beda pula. Keterwakilan populasi dalam sampel penelitian ini ditetapkan sebanyak 58 responden karena jumlah anggota po-pulasi relatif kecil, maka seluruh anggota populasi akan dijadikan sebagai sampel. Dengan demikian, penelitian ini adalah penelitian populasi atau sensus.

Teknik pengambilan sampel da-lam penelitian ini menggunakan purpo-sive sampling yakni teknik pengambilan sampel dengan kriteria tertentu. Kriteria yang digunakan yakni, manajer tingkat menengah yang umumnya terlibat lang-sung dengan kebijakan yang dilaksanakan olehmanajemen 
puncak serta biasanya manajer tingkat menengah adalah pelak-sana keputusan manajemen puncak yang mampu berinteraksi manajemen puncak dan karyawan.

\section{Metode Pengumpulan Data}

Metode pengumpulan data yang digunakan dalam penelitian, yakni: (1) Kuesioner, yaitu melalui pengajuan kuesioner yang terkait dengan TQM, pengukuran kinerja, dan kinerja manajerial;

(2) Wawancara, yaitu dengan mengadakan tanya jawab langsung dengan pihak perusahaan.

\section{Variabel dan Pengukurannya}

Total Quality Management (TQM) adalah konsep dengan seperang-kat prinsipprinsip panduan yang menjadi dasar bagi organisasi yang ingin terus me-nerus melakukan penyempurnaan dan perbaikan yang diukur dengan menggu-nakan elemenelemen utama manajemen kualitas menurut Deborah \& Pricilia (Supratiningrum \& Zulaikha, 2003), dengan indikator: (1)

Kepemimpinan (2) Fokus Pelanggan (3) Pemberdayaan Kar-yawan (4) Perbaikan yang Berkelanjutan (5) Fakta Dasar dalam Pengambilan Ke-putusan (6) Pelatihan dan Pengembangan (7) Penghargaan dan Pengakuan (8) Flek-sibilitas (9) Peralatan dan Teknik Penggu-naannya (10) Perencanaan Strategi (11) Tim Kerja, dan (12) Keterlibatan Pema-sok. Setiap responden diminta menilai penerapan TQM dari sangat tidak setuju (poin 1) berarti TQM rendah sampai dengan sangat setuju (Poin 5) berarti TQM tinggi yang terdiri dari 12 item pertanyaan.

Sistem pengukuran kinerja adalah pemberian informasi kepada manajer dalam unit perusahaan atau organisasi yang dipimpin tentang kualitas dalam aktivitas operasi perusahaan yang diukur dengan menggunakan instrumen yang dikembangkan oleh Khim \& Larry (1998) dan Daniel \& Reitsperger (1992), dengan indikator: (1)
Umpan Balik Pe-langgan (2) Menerima Keluhan Pelang-gan (3) Integrasi Perencanaan Desain (4) Evaluasi Kualitas Kinerja Perusahaan (5) Perbaikan Sistem, dan (6) Menurunkan Komplain Pelanggan. Frekuensi pengu-kuran kinerja manajer yang diukur dalam skala rendah (1) untuk menunjukkan pe-ngukuran kinerja yang rendah dan skala tinggi (5) untuk menunjukkan penguku-ran sistem pengukuran kinerja yang tinggi yang terdiri dari 6 item pertanyaan.

Kinerja manajerial adalah kinerja individu dalam kegiatan-kegiatan manajerial yang diukur dengan menggu-nakan instrumen self rating yang dikem-bangkan oleh Mahoney \& Carrol (1963). Dalam penelitian ini, setiap responden diminta mengukur sendiri kinerjanya di-bandingkan dengan rata-rata kinerja rekan responden. Kinerja manajerial yang diu-kur meliputi delapan dimensi yaitu (1) perencanaan, (2) investigasi, (3) pengko-ordinasian, (4) evaluasi, (5) pengawasan, (6) pemilihan staf, (7) negosiasi, dan (8) perwakilan. Penilaian responden adalah dari poin (1) untuk kinerja rendah dan poin (5) untuk kinerja tinggi yang terdiri dari 7 item pertanyaan.

\section{Metode Analisis Data}

Metode analisis data yang digunakan pada penelitian ini adalah Statistik Deskriptif, Uji Validitas dan Reabilitas, Uji Asumsi Klasik, dan Uji Hipotesis menggunakan uji interaksi atau sering juga disebut dengan Moderated Regression Analysis (MRA) dengan menggunakan regresi berganda dengan menggunakan model interaksi antar variabel dengan bantuan software SPSS for windows. Adapun persamaan yang akan diestimasi adalah sebagai berikut :

$$
\mathrm{Y}=\alpha+\beta 1 \mathrm{X} 1+\beta 2 \mathrm{X} 2+\beta 3 \mathrm{X} 1 \mathrm{X} 2+\mathrm{e}
$$

$\mathrm{Y}=$ Kinerja Manajerial

$\mathrm{X} 1=$ Total Quality Management

X2 = Sistem Pengukuran Kinerja 
$\mathrm{X} 1 \mathrm{X} 2=$ Interaksi $\mathrm{TQM}$ dengan Sistem Pengukuran Kinerja yang diu-kur berdasarkan nilai perkalian antara $\mathrm{X} 1$ dan X2

$\mathrm{b} 1-\mathrm{b} 3=$ koefisien regresi

\section{Hipotesis}

\section{Pengaruh TQM terhadap Kinerja}

Manajerial

Tercapainya kepuasan pelanggan merupakan tujuan perusahaan dalam menghasilkan output yang berkualitas. Salah satu indikatornya adalah berku-rangnya keluhan dari pelanggan, dan hal ini mengarah kepada peningkatan kinerja perusahaan.Penelitian yang dilakukan oleh Madu \& Kuei (1996) menunjukan bahwa terdapat hubungan antara kinerja organisasional dan kualitas.

Tersziovski \&Samson (1999) meneliti tentang elemen-elemen TQM yang dijadikan sebagai sistem penghar-gaan kualitas, dengan melakukan peng-ujian hubungan antara faktor elemen TQM yang dipilih terhadap faktor ki-nerja, dan hasil penelitian mereka adalah elemen TQM mempengaruhi kinerja.

Khim \& Larry (1998) menjelas-kan bahwa Total Quality Management merupakan suatu filosofi yang menekan-kan pada peningkatan proses pemanufak-turan secara berkelanjutan dengan meng-eliminasi pemborosan, meningkatkan ku-alitas, mengembangkan ketrampilan dan mengurangi biaya produksi. Semua ke-giatan tersebut oleh manajer harus dila-kukan dengan efektif dan efisien dengan menerapkan konsep TQM. Hal ini sejalan dengan pendapat Stoner (2006) yang mengungkapkan bahwa kinerja manajerial adalah seberapa efektif dan efisien ma-najer telah bekerja untuk mencapai tujuan organisasi.

Dengan berdasarkan penelitian diatas maka maksud dari penelitian ini adalah menguji kembali bagaiman pe-ngaruh penerapan TQM terhadap kinerja manajerial. Dengan demikian dapat diba-ngun hipotesis yang menghubungkan Total Quality Management (TQM) de-ngan kinerja manajerial sebagai berikut:

\section{Hipotesis 1:}

TQM berpengaruh positif terhadap kinerja manajerial.

\section{Pengaruh Sistem Pengukuran Kinerja terhadap Kinerja Manajerial}

Pengukuran terhadap kinerja adalah suatu hal yang penting dilakukan agar diketahui apakah selama pelaksana-an kinerja terdapat kesenjangan dari ren-cana yang telah ditentukan atau apakah kinerja dapat dilakukan sesuai dengan yang diharapkan. Sistem pengukuran ki-nerja yang dilakukan oleh perusahaan akan memotivasi manajer untuk bekerja lebih baik karena prestasi kerjanya sangat diperlukan perusahaan. Pengukuran ki-nerja merupakan suatu proses yang harus dilakukan dalam upaya pengendalian tenaga kerja, penilaian tersebut dimak-sudkan untuk memperoleh informasi yang akurat dan valid tentang perilaku dan kinerja anggota organisasi. Menurut Kim \& Larry (1998) sistem pengukuran ki-nerja merupakan frekuensi pengukuran kinerja pada manajer dalam unit organi-sasi yang dipimpin mengenai kualitas da-lam aktivitas operasional perusahaan.

Kren menyatakan bahwa informa-si kinerja yang komprehensif dari sistem pengukuran kinerja akan memberikan informasi yang lebih spesifik dan relevan untuk proses pengambilan keputusan, sehingga dapat meningkatkan kinerja manajerial. Kren menemukan bahwa terdapat hubungan positif antara informasi yang berhubungan dengan pekerjaan dan kiner-ja manajerial (Syaiful, 2006).

Penelitian Syaiful

(2006) 
membe-rikan hasil bahwa Sistem Pengukuran Ki-nerja memiliki pengaruh signifikan positif terhadap kinerja manajerial. Hal ini mengindikasikan bahwa informasi kinerja memberikan para manajer prediksi yang lebih akurat tentang keadaan lingkungan, sehingga menghasilkan sebuah pengam-bilan keputusan alternatif yang lebih baik dengan rangkaian tindakan yang lebih efektif dan efisien. Narsa \& Rani (2003), menyatakan bahwa ada pengaruh positif dari interaksi sistem pengukuran kinerja dengan TQM terhadap kinerja manajerial suatu organisasi.

Penelitian lain yang dilakukan oleh Milgrom \& Roberts (Mardiah dan Mardiyah, 2005) menyatakan bahwa suatu organisasi membutuhkan sistem pengukuran kinerja sebagai komplemen dari Sistem Akuntansi Manajemen untuk menghasilkan kinerja yang tinggi, sedangkan penelitian yang dilakukan oleh Mardiah \& Listianingsih (2005) sendiri memberi hasil bahwa sistem pengukuran kinerja berperan dalam hubungan antara total quality management dan kinerja manajerial. Selanjutnya, penelitian yang dilakukan oleh Hertalia (2009) menggam-barkan bahwa sistem pengukuran kinerja memiliki pengaruh yang signifikan positif terhadap kinerja manajerial suatu orga-nisasi.

Dari uraian-uraian di atas dapat diketahui bahwa pelaksanaan sistem pengukuran kinerja akan berpengaruh terha-dap kinerja manajerial. Sistem penguku-ran kinerja merupakan salah satu sarana untuk mengetahui kinerja manajerial se-hingga para manajer diharapkan dapat meningkatkan kinerjanya.

\section{Hipotesis 2:}

Sistem pengukuran kinerja berpe-ngaruh positif terhadap kinerja ma-najerial.

\section{Sistem Pengukuran Kinerja Berperan sebagai Variabel Moderasi antara Total Quality Management dengan Kinerja Manajerial}

Sistem produksi dalam perusahaan bisa berinteraksi dengan sistem akuntansi manajemen dalam menghasilkan kinerja yang lebih tinggi. Penerapan TQM dan frekuensi pelaporan ukuran kinerja pada para karyawan akan menghasilkan kinerja karyawan yang tinggi. Sistem pengukuran kinerja memiliki hubungan dengan prak-tik penerapan TQM, dengan sistem pe-ngukuran kinerja yang terdiri dari serang-kaian ukuran akan dapat menilai kinerja manajerial. Pengukuran kinerja dapat memberikan informasi untuk mengambil keputusan tentang promosi dan gaji.

Perusahaan dengan menerapkan strategi manufakturing atau TQM mengharapkan kinerja kualitasnya menjadi lebih tinggi. Salah satu strategi tersebut adalah dengan meningkatkan frekuensi memberikan informasi ukuran kinerja bagi karyawan, sehingga karyawan bisa menggunakannya untuk memonitoring dan meningkatkan kinerja mereka. Pem-berian insentif dalam bentuk gaji/upah atau bentuk lainnya yang sejenis akan mendorong motivasi karyawan lebih tinggi dan juga tentu saja mendorong kinerja karyawan yang lebih tinggi lagi.

Banker, et al. (1993) memberikan bukti yang empiris bahwa, frekuensi pela-poran ukuran kinerja manufaktur pada karyawan, terkait dengan praktik TQM, implementasi JIT, dan team work. Prog-ram peningkatan kualitas seperti TQM secara individual dapat efektif jika peru-sahaan telah mengimplementasikan cara perbaikan kualitas secara berkesinambu-ngan, dibandingkan dengan organisasi pe-saing lainnya yang mengadakan improve-ment dengan tidak menggunakan teknik TQM. 
Efektifitas tersebut dapat diketahui jika dilakukan pengukuran atas kinerja yang dihasilkan. Yuwono, dkk.(2007) menyatakan bahwa pengukuran kinerja merupakan tindakan pengukuran yang dilakukan terhadap berbagai aktivitas da-lam rantainilai yang ada pada perusa-haan. Berdasarkan pertimbangan tersebut maka dapat dibangun hipotesis sebagai berikut:

\section{Hipotesis 3:}

Sistem pengukuran kinerja berperan sebagai variabel moderasi antara TQM dengan kinerja manajerial.

\section{Hasil dan Pembahasan Deskripsi Variabel}

Berdasarkan hasil perhitungan statistik deskriptif pada tabel 1, untuk pengukuran seluruh variabel dalam peneliti-an ini, menunjukkan bahwa manajer yang menjadi responden dalam penelitian ini memiliki persepsi tentang TQM, Sistem Pengukuran Kinerja, dan Kinerja relatif tinggi yang ditunjukkan oleh nilai rata-rata yang mendekati nilai maksimum kisaran sesungguhnya.

\section{Uji Coba Instrumen}

Asumsi yang digunakan dalam uji validitas adalah jika $\mathrm{r}$ hitung (dilihat pada kolom corrected item-total correlation) lebih besar dari rkritis (rhitung > rkritis) maka item dinyatakan valid. Nilai rkritis yang digunakan untuk pengujian validitas adalah 0,300 (Sugiyono, 2000). Untuk uji reliabilitas, menunjukan bahwa angka-angka dari nilai alpha cronbach's pada seluruh variabel dalam penelitian ini, semuanya menunjukan besaran di atas nilai 0,60. Hal ini berarti bahwa seluruh pertanyaan/pernyataan untuk variabel TQM, Sistem Pengukuran Kinerja, dan Kinerja adalah valid dan reliable. Hasil perhitungan reliabilitas data selengkapnya dapat dilihat pada tabel 2 hingga tabel 7 .

\section{Manajerial}

Berdasarkan hasil uji t, TQM berpengaruh positif signifikan terhadap ki-nerja manajerial dengan nilai thitung sebe-sar 6,260. Nilai koefisien korelasi parsial (r) sebesar 0,771 dan nilai koefisien de-terminasi parsial $\left(\mathrm{r}^{2}\right)$ sebesar $59,4 \%$ (Ta-bel 8). Hal ini mencerminkan bahwa upa-ya perusahaan dalam peningkatan kualitas melalui TQM pada perusahaan yang ter-gabung dalam Fajar Grup berpengaruh terhadap kinerja manajerial. Kondisi ini menggambarkan bahwa partisipasi selu-ruh individu dalam perusahaan, terutama para manajer dalam proses pembentukan kualitas untuk seluruh aspek dalam peru-sahaan tidak hanya sebagai bentuk for-malitas kegiatan rutin saja pada setiap ta-hun, karena yang berperan penting dalam proses tersebut adalah para manajer sela-ku pejabat yang berwenang. Dalam artian bahwa manajerlah lebih mendominasi untuk melakukan pengendalian di dalam proses peningkatan kualitas perusahaan.

Hasil penelitian sejalan dengan hasil penelitian Pasaribu (2009); Bekka (2007); Jumirin (2006); Suprantiningrum \& Zulaikha (2003), serta Narsa \& Yuniawati (2003), yang umumnya mela-kukan test hubungan antara faktor elemen TQM yang dipilih terhadap faktor kinerja dan mereka menyimpulkan faktor elemen TQM mempengaruhi kinerja. Sistem Pengukuran Kinerja berpengaruh positif terhadap Kinerja Manajerial

Berdasarkan hasil uji $\mathrm{t}$ pada bab sebelumnya menunjukkan bahwa variabel sistem pengukuran kinerja berpengaruh positif signifikan terhadap kinerja mana-jerial dengan nilai thitung sebesar 2,431. Nilai koefisien korelasi parsial (r) sebesar 0,803 dan nilai koefisien determinasi par-sial $\left(\mathrm{r}^{2}\right)$ sebesar $64,5 \%$. (Tabel 8). Hasil pengujian hipotesis menunjukkan bahwa sistem pengukuran kinerja memiliki pe-ngaruh 
signifikan positif terhadap kinerja manajerial. Hal ini dapat diindikasikan bahwa sistem pengukuran kinerja yang diterapkan di perusahaan industri mem-bantu meningkatkan kinerja manajerial perusahaan dan dasar untuk mencapai tujuan dari perusahaan tersebut, dengan kata lain semakin baik sistem pengukuran kinerja oleh masing-masing perusahaan yang berada pada Fajar Grup maka ki-nerja manajerial juga akan semakin me-ningkat.

Hasil penelitian sejalan dengan hasil penelitian Narsa \& Yuniawati (2003); Mardiah \& Listianingsih (2005), serta Rahman (2006), yang menyatakan bahwa sistem pengukuran kinerja berpe-ngaruh signifikan positif terhadap kinerja manajerial.

Interaksi TQM dengan Sistem Pengukuran Kinerja berpengaruh positif terhadap Kinerja Manajerial

Hasil uji t juga menunjukkan bah-wa interaksi TQM dengan sistem pengu-kuran kinerja berpengaruh positif signi-fikan terhadap kinerja manajerial dengan nilai thitung sebesar 4,916. Nilai koefisien korelasi parsial (r) sebesar 0,717 dan ni-lai koefisien determinasi parsial $\left(\mathrm{r}^{2}\right)$ sebe-sar $51,4 \%$, (Tabel 8). Hal ini menunjuk-kan bahwa sistem pengukuran kinerja da-pat dijadikan sebagai variabel moderasi dalam mendorong hubungan antara TQM dengan kinerja manajerial pada perusa-haan yang berada pada Fajar Grup.

Hasil penelitian sejalan dengan penelitian Banker et al (1993), membe-rikan bukti yang empiris bahwa, frekuensi pelaporan ukuran kinerja manufaktur pada karyawan, terkait dengan praktik TQM, implementasi JIT, dan team work. Hasil penelitian juga sejalan dengan pe-nelitian Yuwono dkk (2007), yang me-nyatakan bahwa pengukuran kinerja me-rupakan tindakan pengukuran yang dila-kukan terhadap berbagai aktivitas dalam rantai nilai yang ada pada perusahaan. Hasil penelitian lain yang sejalan dengan penelitian ini antara lain Narsa \& Yuniawati (2003); Kurnianingsih (2000); Supratiningrum \& Zulaikha (2003); Yuniawati (2003); Jumirin (2006); Mintje (2013), dan Kumentas (2013), yang me-nemukan pengaruh signifikan dari inte-raksi TQM dan sistem pengukuran kiner-ja terhadap kinerja manajerial.

\section{Simpulan dan Saran}

Berdasarkan hasil analisis di atas maka dikemukakan kesimpulan sebagai berikut.

1. Total Quality Management adalah konsep dengan seperangkat prinsip-prinsip panduan yang menjadi dasar bagi organisasi yang ingin terus me-nerus melakukan penyempurnaan dan perbaikan berpengaruh positif terha-dap kinerja manajerial pada Fajar Grup. Semakin tinggi frekuensi pene-rapan TQM akan mempengaruhi ki-nerja manajerial pada Fajar Grup. Hasil penelitian sejalan dengan hasil penelitian Pasaribu (2009), Bekka (2007), Jumirin (2006), Supranti-ningrum \& Zulaikha (2003), Narsa \& Yuniawati (2003), Tersziovski \& Samson (1999), dan Madu \& Kuei (1996).

2. Sistem pengukuran kinerja adalah pemberian informasi kepada manajer dalam unit perusahaan atau organisasi yang dipimpin tentang kualitas dalam aktivitas operasi perusahaan yang berpengaruh positif terhadap kinerja manajerial pada Fajar Grup. Semakin tinggi frekuensi penerapan sistem penguran kinerja maka akan mempengaruhi kinerja manajerial pada Fajar Grup. Hasil penelitian sejalan dengan penelitian Rahman (2006), Narsa \& Yuniawati (2003) dan Mardiah \& Listianingsih (2005).

3. Hasil analisa moderasi menunjukkan bahwa interaksi TQM dengan sistem 
pengukuran kinerja mempengaruhi kinerja manajerial pada Fajar Grup. Semakin sering menggunakan sistem pengukuran kinerja dalam penerapan TQM akan mempengaruhi kinerja manajerial pada Fajar Grup. Hasil penelitian sejalan dengan penelitian Narsa \& Yuniawati (2003), Retno (2000), Zulaikha (2003), Yuniawati (2003), Jumirin (2006), Mintje (2013), Kumentas (2013).

4. Sistem pengukuran kinerja dalam peneltian ini gagal menjadi variabel moderasi murni atau dapat dikatakan sistem pengukuran kinerja hanya se-bagai variabel moderasi semu karena nilai t dan nilai koefisien dari variabel interaksi TQM dan sistem pengukuran kinerja tersebut tidak lebih kuat bila dibandingkan dengan nilai $\mathrm{t}$ dan nilai koefisien dari variabel TQM sebagai variabel yang mempengaruhi lang-sung kinerja manajerial, sehingga meskipun tidak ada sistem penguku-ran kinerja sebagai variabel moderasi, TQM tetap berpengaruh terhadap kinerja manajerial.

\section{Saran}

Berdasarkan kesimpulan yang telah dikemukakan, maka dikemukakan saran dari hasil penelitian ini sebagai be-rikut.

1. Untuk mendapatkan hasil penilaian kinerja manajer yang objektif, disaran-kan bagi penelitian selanjutnya untuk menggunakan konsumen sebagai responden.

2. Penilaian kinerja manajerial sebaiknya tidak menggunakan self rating karena penilaiannya kurang objektif, sehingga penting bagi penelitian selanjutnya un-tuk menggunakan penilaian karyawan.

3. Penelitian selanjutnya sebaiknya menggunakan komponen utama sistem akuntansi manajemen yang lain seba-gai variabel moderating yaitu sasaran kinerja dan sistem reward.

\section{Daftar Rujukan}

Banker R., Potter G. \& Schroeder R. (1993). Reporting Manufacturing

Performance Measures to Wor-kers: An Empirical Study. Journal of Management Accounting Re-search:33-35.

Bekka J.M. (2007). Pengaruh Total Qua-lity Management (TQM) terhadap Kinerja Manajerial pada Industri Kayu Olahan di Kota Palu. Jurnal Transaksi Edisi 4 Tahun II.

Daniel, S., \& W. Reitsperger. 1992. "Lin-king Quality Strategy with Mana-gement Control Systems: Empi-rical Evidence from Japanese Industry". Accounting, Organiza-tions and Society $17: 601-618$.

Hansen D.R. \& Mowen M.M. (2004). Management Accounting. Edisi 7. Jakarta: Salemba Empat.

Itter C. \& Larcker D.F. (1995). Total Quality Management and the Choice of Information and Re-ward Systems. Journal of Accounting Research (supple-ment): 1-34.

Jumirin. (2006). Persepsi Manajemententang Pengaruh TQM terhadap Kinerja Manajerial dengan Fak-tor Kondisional sebagai Variabel Moderating pada PDAM Tirta-nadi Provinsi Sumatara Utara (Tesis). Medan: Universitas Su-matera Utara.

Khim S.L. \& Larry K.N. (1998). The Performance Effects of Comple-mentarities between Manufactu-ring Practice and Management Accounting System. Journal of Management Accounting Re-search 10:325-346.

Kumentas N.C. (2013) Pengaruh TQM, 
Sistem Pengukuran Kinerja dan Penghargaan terhadap Kinerja Manajerial PT Pos Indonesia, Jurnal EMBA Volume 1 No.3 Juni 2013, Hal. 796-805.

Kurnianingsih R. (2000). Pengaruh Sistem Pengukuran Kinerja dan Sistem Penghargaan terhadap Ke-efektifan Penerapan Teknik Total Quality Management. Studi empi-ris pada Perusahaan Manufaktur di Indonesia. Seminar Nasional Akuntansi.

Mahoney, T.A., Jerdes, T.H. \& Carroll, S.J. 1963. Development Manage-rial Performance: A Research Ap-proach, Southwestern Publishing Co.

Mardiyah A.A. \& Listianingsih. (2005). Pengaruh Sistem Pengukuran Ki-nerja, Sistem Reward dan Profit Center terhadap Hubungan Antara Total Quality Management de-ngan Kinerja Manajerial. Jurnal SNA VIII. Solo. 2005.

Mintje N. (2013). Pengaruh TQM, Sistem Penghargaan dan Sistem Pengu-kuran Kinerja terhadap Kinerja Manajerial pada PT Air Manado, Jurnal EMBA Vol.1 No.3 Septem-ber 2013, Hal. 52-62.

Narsa M.I. \& Yuniawati D.R. (2003). Pengaruh Interaksi Total Quality Management dengan Sistem Pengukuran Kinerja dan Sistem Penghargaan terhadap Kinerja Manajerial. Jurnal Akuntansi dan Keuangan Vol. 5 No.1. Mei 2003.

Pasaribu H. (2009). Pengaruh Komitmen,

Persepsi dan Penerapan Pilar Da-sar

Total Quality Management ter-hadap Kinerja Manajerial (Survei pada BUMN Manufaktur di Indo-nesia). Jurnal Akuntansi \& Keu-anganVol. 11, No. 2. November 2009: 65-75.

Powell T.C. (1995). Total Quality
Mana-gement and Competitive Advan-tage: A Review and Empirical Study. Strategic Management Journal 16: $15-37$.

Rahman S. (2006). Pengaruh Sistem Pengukuran Kinerja terhadap Keje-lasan Peran, Pemberdayaan Psiko-logis, dan Kinerja Manajerial. SNA X. Hal 1-35.

Stephen, George. 1994. Total Quality Management, John Wiley \& Sons Inc, New York

Sugiyono. (2000). Statistika untuk Pene-litian, Bandung: Alfabeta

Supratiningrum \& Zulaikha. (2003). Pengaruh Total Quality Management terhadap Kinerja Manajerial dan Sistem Pengukuran Kinerja dan Sistem Penghargaan (reward) sebagai Variabel Moderating. Simposium Nasional Akuntansi VI. Surabaya, 16-17 Oktober 2003.

Wolner G.E. (1992). The Law of Produ-cing Quality. Quality Progress, pp. 35-40.

Wruck K.H. \& Jensen M.C. (1994). Science, Specific Knowledge and Total Quality Management. Jour-nal of Accounting and Economics: 247-287.

Yuniawati. (2003). Pengaruh Interaksi antara TQM dengan Sistem Peng-ukuran Kinerja dan Sistem Peng-hargaan terhadap Kinerja Mana-jerial. Jurnal Akuntansi \& Keu-angan Vol.5 Mei, 18 - 34. Sura-baya: Universitas Airlangga.

Yuwono S., Sukarno E. \& Ichsan M. (2007). Petunjuk Praktis Penyusu-nan Balanced Scorecard: Menuju Organisasi yang Berfokus pada Strategi. Jakarta: PT Gramedia Pustaka Utama. 